\title{
Developing Red Chilli Downstream Business in Simalungun District
}

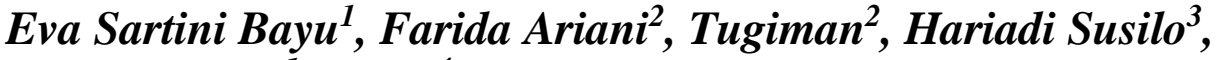 \\ Ma'ruf Tafsin', Tulus ${ }^{4}$ \\ ${ }^{1}$ Faculty of Agriculture, Universitas Sumatera Utara, Medan \\ ${ }^{2}$ Faculty of Engineering, Universitas Sumatera Utara, Medan \\ ${ }^{3}$ Faculty of Cultural Science,Universitas Sumatera Utara, Medan \\ ${ }^{4}$ Faculty of Mathematics and Natural Science, Universitas Sumatera Utara, Medan
}

\begin{abstract}
This training held at Gondang Rejo Farmers Group, Bandar Huluan District, Simalungun District. The purpose of this training is (1) provide broader knowledge to farmers in handling post-harvest red chili; (2) train and guide farmers in managing red chili to become a durable food product; and (3) increasing the economic value of red chili so that farmers do not experience losses when the harvest is abundant, and the price of chili is low. Development of local commodities, especially red chili; providing training material in the process of product manufacturing and packaging; Implementation of this training is the processing of fresh red chili into powdered red chili using a simple dryer and grinder capable of producing chili powder products that have a longer shelf life and are in accordance by the standard.The outcome will developed skill abilty,built networking and encourage red chilli farmers interest to increase the amount of production for continuity the supply side. By developing the downstream red chilli it could increase the income of the red chili farmers.
\end{abstract}

Keywords: Chilli powder, Developing of agricultural products

Abstrak. Pelatihan ini diadakan di Kelompok Tani Gondang Rejo, Distrik Bandar Huluan, Kabupaten Simalungun. Tujuan dari pelatihan ini adalah (1) memberikan pengetahuan yang lebih luas kepada petani dalam menangani cabai merah pascapanen; (2) melatih dan membimbing petani dalam mengelola cabai merah untuk menjadi produk makanan yang tahan lama; dan (3) meningkatkan nilai ekonomi cabai merah sehingga petani tidak mengalami kerugian saat panen melimpah, dan harga cabai rendah. Pengembangan kearifan lokal, seperti pengolahan cabai merah; menyediakan materi pelatihan dalam proses pembuatan dan pengemasan produk; Penerapan pelatihan ini adalah pengolahan cabai merah segar menjadi cabai merah bubuk menggunakan pengering dan penggiling sederhana yang mampu menghasilkan

*Corresponding author at:Jalan Prof A. Sofyan No 3, Kampus USU, Medan 20155

E-mail address: evasartinibayu@usu.ac.id 
produk bubuk cabai yang memiliki umur simpan lebih lama dan sesuai dengan standar. Hasilnya akan mengembangkan keterampilan, membangun jejaring, dan mendorong minat petani cabai merah untuk meningkatkan jumlah produksi demi kelangsungan sisi pasokan. Dengan mengembangkan produk hilir cabai merah dapat meningkatkan pendapatan dari petani.

Kata Kunci: Bubuk cabai, Pengembangan produk pertanian

Received 15 October 2018| Revised 5 February 2019| Accepted 20 February2019

\section{Introduction}

Developing of agricultural products is the process of bringing agricultural producer closer to consumers with the aim of increasing the value of agricultural products, through agriculture production recommended by the World Food Conference can only be achieved through the increase implementation through hilirization, agribusiness will get added-value and market guarantees which will ultimately improve the welfare of the Indonesian people. Besides, the downstream industry program initiated by the Ministry of Industry since 2010 is intended to obtain the added value of raw material products, strengthen industrial structures, provide employment, and business opportunities in Indonesia. One agricultural product that requires downstream is red chilli.

Redchilli (Capsicum annum L.) is one of the horticultural commodities that has economic value and plays an important role in human life because in addition to being a nutrient producer, it is also a mixture of food and medicine [1]. Chili contains approximately $1.5 \%$ (usually between $0.1-1 \%$ ) a spicy taste. The spicy taste caused by capsaicin and dihydrocapsaicin contain [2]. Besides chilli also contains various other nutrients such as water, energy, protein, fat, carbohydrates, fiber, ash, calcium, phosphorus, iron, vitamin $\mathrm{A}$, vitamin $\mathrm{C}$, thiamine, riboflavin, niacin and ascorbic acid [3].

Market demand for red chili is quite high, both for the domestic market and for export to foreign countries, such as Malaysia and Singapore [4]. So far there are two types of red chilli, sizeable large and curly. Most Indonesians consume chilli in fresh, dry or processed form.

The planting area is extensive because it can be cultivated in the lowlands and highlands so that many farmers in Indonesia planted red chili [5,6]. One of them is a farmer in the guided village of Huta Gondang Rejo, Nagori Bandar Tongah, Bandar Huluan District, 
Simalungun District. The members of the Gondang Rejo farmer group totaled 15 people, with an area of agricultural land managed, namely 39,088 Ha.

Increased production of red chilli at certain times often causes a decrease in the price of red chili on the market. Besides, red chilli has the same characteristics as other agricultural products that are easily damaged. Therefore, efforts need to made so that in addition to extending shelf life, it can also maintain and even increase its economic value through the processing of red chili into other processed products such as chili powder. An effort to stabilize the price of red chilli can be done through the planning and implementation of production improvement programs support by in put management so as to increase the productivity of fresh red chilli [7].

\section{Methods}

This training consists of three methods, namely:

1. Providing counseling on the application of science and technology in the development of local commodities, especially red chili.In this activity, the implementation team first approached the red chili farmers group and explained the background, objectives, and benefits of this activity as well as the importance of science and technology to improve the economic value of the red chili harvest in overcoming fluctuations in red chili prices.

2. Provide training materials related to the product manufacturing and packaging process.

3. The implementation team prepared materials in the form of handouts distributed to the group members who participated in these activities related to the process of processing fresh red chili products which are an alternative in post-harvest handling, consisting of an explanation of the operation of dryers and simple grinders, an explanation of internal cleanliness. The production process was red chili drying process, milling process, product packaging and selling price determination.Make an analysis of the selling price of the product based on production costs.

4. The implementation team explained how to determine the selling price based on production costs so that the group of red chili farmers did not experience losses.

Procedure for making chilli powder

a. Sorting

Sorting (selection) aims to choose good quality fresh red chilli, which is a level of maturity above $60 \%$, healthy and physically smooth (not disabled). Chilli stalks and damaged parts discarded. 
b. Washing

Washing aims to remove dirt and remnants of pesticides. Washing was done until clean, then drained to dry.

c. Division

Division aimed speeding up the drying time.

d. Blanching

Blanching aims to speed up drying time, prevent browning and extend shelf life. It also prevents chilli from becoming wrinkled, and the color is not dull due to the drying process. The blanching process is carried out by soaking the red chilli which is already clean in hot boiling water $\left(90^{\circ} \mathrm{C}\right)$ and has given potassium metabisulfite $\left(\mathrm{K}_{2} \mathrm{~S}_{2} \mathrm{O}_{5}\right)$ or Sodium bisulfite $\left(\mathrm{Na}_{2} \mathrm{~S}_{2} \mathrm{O}_{5}\right)$ with a concentration of $0.2 \%$ or as much as $2 \mathrm{~g} / 1$ of water for \pm 6 minutes. The hot water needed to soak the chili is $1 \mathrm{~kg}$ of chili is needed $\pm 1.5 \mathrm{~L}$ ). Furthermore, the chilli that has soaked is removed and put into cold water, so the healing process stops. Then the chilli is drained and ready to dry.

e. Drying

After blending, chilli can be dried immediately or dried with a dryer. However, to speed up the drying time and improve the quality of chili, drying is done with an artificial dryer (oven) at a temperature of $60^{\circ} \mathrm{C}$ for $10-15$ hours. At this stage the temperature of the dryer must be considered not to exceed $60^{\circ} \mathrm{C}$. When drying, the ingredients should be reversed every 3-4 hours to dry evenly. Drying can stop if the water content has reached $7-8 \%$ or if dried red chilli easily broken.

f. Milling

The dried red pepper is mashed using a hammer mill. The sieve hole used to make chilli powder is 60 mesh so that the red chili powder is smooth evenly.

g. Packaging

Chilli powder products are packed in plastic bottles and labeled containing the product name, composition, net weight, and expiration date. The purpose of this packaging is to protect the product so that it can store longer and to facilitate marketing.

\section{Results and Discussion}

The training began with counseling provided by the implementing team with some material that explained the background and benefits of this activity so that the Gondang 
Rejo red chili farmers group knew and understood the benefits of this activity. This is attractive for chilli farmers, as an alternative to overcome the unstable fresh chilli price.

Furthermore, the farmers gave training how to operate production equipment and packaging. Besides, the implementation team also explained how to process chilli powder with various flavors to produce varied products. The implementing team explained about packaging and labeling process with the aim of facilitating marketing and attracting the attention of consumers to buy the product. The training was attended by 15 people determined by the head of district from members of the Gondang Rejo farmers groupwith different ages and educational backgrounds. By participating attended training help participant understood step by step from sorting until milling process. The implementation of this activities will develope skill abiltybuilt networking and encourage red chilli farmers interest to increase the amount of production for continuity the supply side. The reliance on fresh red chilli may aggravate price fluctuation, so consumption pattern should gradually shift to the consumption of dried red chilli powder or pastes [7].

\section{Conclusions}

This training will developed skill ability, built networking and encourage red chilli farmers in overcoming problems in the form of chili price fluctuations, namely by processing red chili into chili powder. By developing the downstream red chilli it could increase the income of the red chili farmers.

\section{References}

[1] Rompas, J. P. 2001. Efek Isolasi Bertingkat Colletotrichum capsici Terhadap Penyakit Antraknosa Pada Buah Cabai. Prosiding Kongres Nasional XVI dan Seminar Ilmiah. Bogor, 22-24 Agustus 2001. Perhimpunan Fitopatologi Indonesia. 163.

[2] Lukmana, A. 2004. Agribisnis Cabai. Penebar Swadaya. Jakarta.

[3] Ashari. 2006. Holtikultura Aspek Budidaya. Universitas Indonesia. Jakarta.

[4] Sembiring, N. N. 2009. Pengaruh Jenis Bahan Pengemas terhadap Kualitas Produk Cabai Merah (Capsicum annuum L.). Tesis. Pasca-sarjana Universitas Sumatera Utara, Medan.

[5] Kusandriani, Y. 1996. Pengaruh naungan kasa terhadap hasil beberapa kultivar cabai. Jurnal Hortikultura 6(1): 10-16.

[6] Ameriana, M., W. Adiyoga, dan L. Setiawati. 1998. Pola konsumsi dan selera konsumsi cabai dan kentang tingkat lembaga. Buletin Penelitian Hortikultura 8(3): 1233-1241. 
[7] Sativa, M. M. Harianto., Suryana, A. 2017. Impact of Red Chilli.Reference price Policy in Indonesia. Int.J.Agr.Syst. 5(2): 120-139. 